\title{
Political Economy of State Homeland Security Grants
}

\author{
Michael J. Dueker and Christopher Martinek
}

$\mathrm{O}$ n October 4, 2006, President Bush signed the Department of Homeland Security (DHS) Appropriations Act for fiscal year 2007. The law provides $\$ 525$ million for state homeland security grants and, as in previous years, allocates the funds according to a formula written into law by the Patriot Act. This formula guarantees each state 0.75 percent of the total funds appropriated in a fiscal year for state and local terrorism preparedness grants. In the initial years of the program, the allocation of remaining funds was left to the discretion of the DHS, which distributed the remaining funds according to each state's share of the national population.

In June 2004, the 9/11 Commission report recommended against the population-based distribution of these grants.

The Commission favored instead an allocation based on risk and vulnerability. Critics of the state grant formula pointed to Wyoming's total grant receipts per capita, which were the largest among all states because Wyoming has the smallest share of national population. In contrast, states such as California and New York, with a presumably greater terrorist threat, received much less per capita funding.

The U.S. House and Senate responded to the $9 / 11$ Commission by seeking to base state grant levels more on risk assessments and less on population, while still guaranteeing a minimum share to each state. The distinct House and Senate proposals serve as a case study in political economy, in the way political bodies seek to allocate economic resources. The House bill proposed a state minimum allocation of 0.25 percent; the Senate bill proposed 0.55 percent. These numbers are interesting: In the House, each state has a minimum voting share of $1 / 435$ or 0.23 percent of the representatives. In the Senate, the allocation of two senators for each state, regardless of population, increases the relative representation for small states in the full U.S. Congress to a minimum of $3 / 535$ or 0.56 percent. It is remarkable how close these two percentages are to the minimum allocations that the House and Senate proposed. Political economy considerations would suggest that the median voter on this issue in the Senate would be from a state with below-average population-hence, the relatively generous 0.55 percent minimum share.
In conference committee, however, the House and Senate did not agree on whether or how to amend the Patriot Act, so each state's 0.75 percent minimum share has remained intact. Instead, the House and Senate decided to cut the size of the state grant program, both in its share of DHS spending and in absolute terms. In addition, the state grant funds not committed by the minimum guaranteed levels are to be distributed according to risk and not simply population.

Accordingly, the attached chart shows how per capita grants to the states shifted between 2005 and 2006. The distribution of per capita grants across states became much more concentrated in the range of $\$ 1$ to $\$ 3$ per capita in 2006 and grants above $\$ 13$ were eliminated by reducing the program's overall funding. Congress may have wanted to reduce the per capita grants to the smallest states (seen as an excessive amount by some) from about $\$ 18$ to about $\$ 13$ (about 30 percent).

This reduction in funding to the state grant program achieved roughly the same result for the smallest states that the change from a 0.75 percent to a 0.55 percent minimum share would have achieved. Total spending on homeland security was not cut as drastically as the state grants; instead, Congress chose to channel resources through alternative programs not subject to the 0.75 percent minimum share per state.

\section{State Homeland Security Grants per Capita}

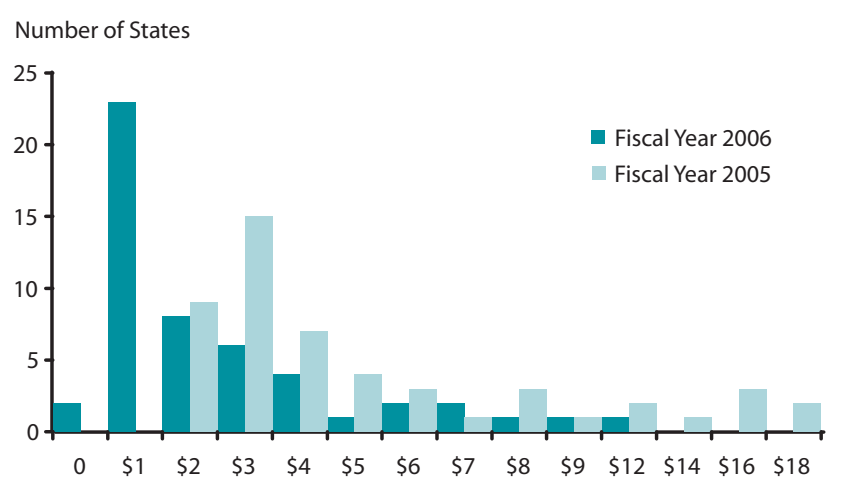

